\title{
Assessment Models in Early Childhood Based on Android to Increase Competency of Pedagogic Teachers of Kindergarten
}

\author{
Sofiah Hartati \\ Early Childhood Education Program \\ Universitas Negeri Jakarta, Indonesia \\ sofiahhartati@unj.ac.id
}

\author{
Hikmah \\ Early Childhood Education Program \\ Universitas Negeri Jakarta, Indonesia \\ hikmah@unj.ac.id
}

\author{
Niken Pratiwi \\ Early Childhood Education Program \\ Universitas Negeri Jakarta, Indonesia \\ nikenpratiwi@unj.ac.id
}

\begin{abstract}
Assessment activities are important in the learning process in kindergarten. The results of the preliminary study were mostly carried out manually and limited to certain assessment techniques. This study seeks to draft a technology application for assessment in kindergarten. The purpose of this study is to help kindergarten teachers conduct assessments easily and interestingly and can communicate directly with parents through the android online application. This study developed a draft assessment model for early childhood development based on online android "MATAGURU". The Android-based early childhood development assessment model was developed through the development of a model by Borg and Gall (2003). This assessment model includes several assessment techniques that can record all aspects of early childhood development. Through this application, can be recorded quickly about early childhood development, accurately and comprehensively. Subsequent research will be tested on the effectiveness of the child development assessment model with the application of "MATAGURU" in the DKI Jakarta Kindergarten, Indonesia.
\end{abstract}

Keywords: assessment, early childhood, development, kindergarten teacher

\section{INTRODUCTION}

Assessment is an important part that must be done by the teacher in the learning process in kindergarten. Through the results of the assessment the teacher can decide on the right program to be presented in learning in kindergarten. In the assessment the teacher will monitor the development achievements of each student so that the teacher can decide the right stimulus for each child.

Early childhood development assessment is the process of gathering, uniting, and interpreting information about early childhood development and learning (Epstein, 2004). Assessment in early childhood is carried out to find out and describe the potential that exists in the child and see changes in that potential after stimulation is given.

Child development assessment helps teachers and parents see the child's development in more detail and see the potential that is owned by the child. Assessment in early childhood is carried out throughout the process of children's learning activities and also looks at children's learning outcomes.

Assessment is not only useful for teachers, but also can be input for parents in an effort to provide ongoing stimulus for optimal child growth and development. The form of early childhood development assessment used by kindergarten teachers is generally informal.

Informal assessment is also known as authentic or naturalistic assessment. According to Feeney, authentic assessment is an assessment conducted during a child's learning activities in real life settings and in natural conditions (Feeney, Christensen, Moravcik, 2006).

Authentic assessment is also useful for making learning plans, making arrangements and seeing the child's learning progress. The teacher's ability to use authentic assessments is also still low. In 2016 researchers also developed a draft model of early childhood development assessment showing that Kindergarten teachers could basically do an authentic assessment process but have not used all the required observation techniques (Hartati, 2006).

Implementation of assessments that are often done is limited to anecdotal records, rating scales, and portfolios, there are already a small number of teachers who already know about some other assessment techniques such as time sampling and the use of technological tools although they need simpler technical instructions.

Based on this, it is necessary to develop an application model for early childhood development based on Android applications. Along with advances in technology, this research needs to be done which will produce an early childhood development assessment model and an android-based application.

This virtual early childhood development assessment model is expected to help teachers in conducting early childhood developmental assessments 
easily and also have an impact on improving Kindergarten teacher's pedagogical competence.

\section{ESSENCE OF EARLY CHILHDOOD ASSESSMENT}

\section{A. Assessment in Early Childhood}

The child development assessment has an important goal which is to find out about the development and knowledge possessed by each child. The assessment is also a source of information for the teacher's part to help the teacher help and support the child to obtain his knowledge. The assessment is also used to make decisions about curriculum development, children's needs, and the right program to help children develop optimally.

In conducting assessments, teachers generally have made guidelines to collect data needed as information about child development and the results of program implementation. According to Goodwin and Goodwin in Wortham, assessment is the process of determining through observation or testing on a person's innate traits or behavior, program characteristics, and then determined in numbers, judgments or scores (Wortham, 2005). Assessment can be done by making observational guidance or observations to obtain an assessment of the child's development.

Assessment in early childhood can help teachers to observe and obtain information about all aspects of child development. Kostelnik explained that, each of these teachers is involved in ongoing, strategic, and purposeful assessment and evaluation. Daily, they are active in documenting what the children in their classroom know and will need to know, the progress being made towards learning and developmental goals, and whether various aspects of their program are supporting each child's growth (Kostelnik, 2007). Early childhood educators must understand the assessment, know the strategies that can be used in conducting the assessment, and understand the purpose of the assessment and evaluation.

Assessment is needed to see what children need and how children should learn. The assessment is not only needed by the teacher as a reference in making learning plans, but also for parents to support ongoing stimulation for children. The National Education Goals Panel in 1998 in Seefeldt explains that teachers and parents want to know how their children are doing, school administrators want to know how effective their programs are, and policy makers want to judge the worth of policies (Seeefeldt, Castle, and Falconer, 2010). Assessments need to be carried out to assist teachers, parents, and schools in designing programs that meet the needs of children, and broadly also become a consideration of policy makers in making policies for early childhood education.

\section{B. Assessment Technique}

In the authentic assessment, continuous and indepth observations are needed. The following are some recording techniques in observation: (1) anecdotal record; (2) running record; (3) time sampling; (4) event sampling; (5) checklist; and (6) rating scale. Anecdotal records are written descriptions or depictions of the child's behavior. Anecdotal records contain events or events, the time and place of the event. According to Driscoll in Wortham, anecdotal notes have five characteristics, are the result of direct observation, fast, accurate and specific records of an event or event, include the context of behavior, as an interpretation of events or events recorded separately, and focus on behavior, be it unique or unusual in the child being observed.

Running Record is used to record the child's behavior in detail which is described in narrative form and based on the sequence of events. Wortham explained that Running records include everything that happened during the time of observation, all observed behaviors, not just special events as in anecdotal records (wortham,loc.cit). Observer can provide comments and analysis of behavior after recording for observed behavior. Time sampling is to record how often or to see the frequency of a behavior occurring within a predetermined time period. Event sampling is used as part of time sampling, for example when a behavior tends to occur within a certain time rather than happening in another time period.

Event sampling is a type of cause and effect observation, when observing this the observer looks for clues that will help in solving a child's problem. By observing event sampling techniques, the observer can learn how to place and deal with children's problems.

Checklist is a list of sequential behaviors in which are arranged in a system of a category. Checklists are useful when there are many behaviors that an observer wants to observe, so it is necessary to make a list of observations of behaviors that appear in children. Rating Scale is used to determine the level of ability of children, this is indicated by a behavior or quality of the behavior. Rating scale helps the teacher in evaluating to see the behavior exhibited by the child at a certain time.

\section{Assessment ECE Based on Android}

According with the importance of early childhood assessment, the development of the assessment is also important, especially in relation to the use of technology, such as Android, as a way to facilitate the access of teachers in recording information about early childhood development. Kindergarten teachers will more easily carry out the learning process by utilizing android technology devices. Thus learning will be more effective, more interesting, and more comprehensive.

Android-based Multimedia Method for early childhood, can facilitate the teacher as an android user when doing learning activities, including assessing early childhood development. By using Android, the teacher is expected to be able to improve the development of motivation, children's interest in learning activities. It can be concluded that the use of Android by kindergarten teachers in their task of carrying out early childhood development assessments, in essence will have implications for the implementation of teacher assignments that are more effective, more interesting, more enjoyable and easier to find information about all aspects of early childhood development.

Various advantages of using android in general, among others: (1) make it easier to write reports; (2) tools that are easy to use; (3) accelerate the work of teachers; (4) not boring for teachers when doing work; (5) easy to revise if something goes wrong; and (6) directly save 
data. Thus the use of assessments through the android application should be developed as an assessment model for teachers in kindergartens.

\section{METHOD}

This research seeks to make a draft application of technology to conduct assessments in kindergartens. The purpose of this research is to help kindergarten teachers conduct assessments easily and attractively and can communicate directly with parents through an online android application. Design and development research are defined for the education domain as the systematic study of design, development and evaluation processes with the aim of establishing an empirical basis for the creation of instructional and non-instructional products" (Richey and Klein, 2007). This study was designed based on research and development by Borg \& Gall (2003).

In the year, the research output is divided into three things starting in 2018 until 2020, namely research on instrument development, prototype technology development and product implementation and collaboration with stakeholders. Based on the strategic plan and previous research, the researcher made a research road map. in the first year drafted the development of an Android-based early childhood development model for kindergarten teachers and a prototype assessment model guide was produced. This year, an Android-based application will be produced that can be used by teachers to conduct development assessments for children. The following is a prototype description of the Android-based child development assessment application model that will be developed (Figure 2).

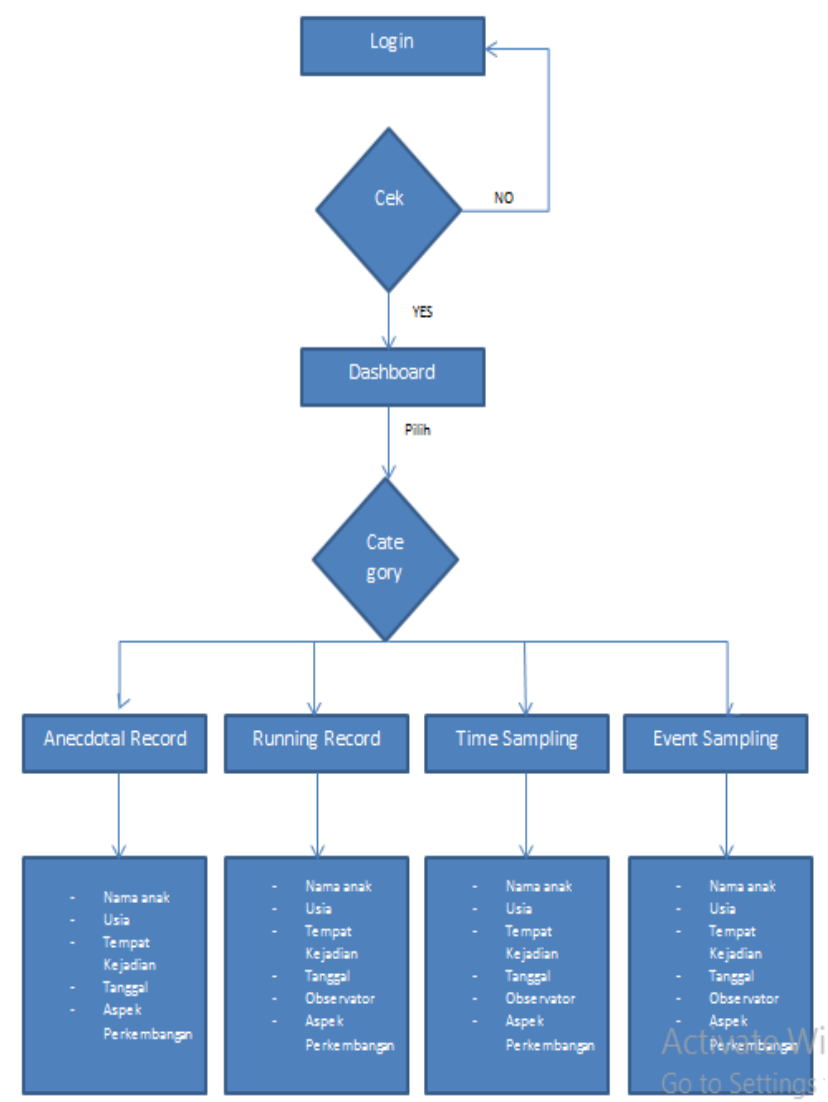

Figure 1 Flowchart of Application

\section{DISCUSSION AND RESULT}

The Android-based Early Childhood Development Assessment Model was developed through the development of a model by Borg and Gall (2003). This assessment model includes several assessment techniques that can record all aspects of early childhood development. The design of this application is based on the results of research by looking at the needs of assessment techniques commonly used by kindergarten teachers. Through the application to be developed, it is hoped that rapid, accurate and comprehensive early childhood development can be recorded.

\section{A. Model Assessment Guidelines}

The concept of the development assessment model is made in the form of a guide that will be used in facilitating the process of conducting the assessment in the school where the trial is conducted. The guide to the development assessment model in kindergarten was made as a form of preliminary design of the model that will be used in research in the first year.

Based on discussions with the research team, the results of the initial research analysis serve as the basis for developing an online android-based child development assessment model. Improvements to the previous child development assessment model include a review of material on the concept of assessment, early childhood development and assessment techniques that can be used by teachers.

One of the assessment contents is to include indicators of child development that are in accordance with the standard level of child development achievement based on Minister of Education and Culture Regulation. By referring to the standard level of achievement of child development, teachers can write indicators that can be achieved by children in play and learning activities in kindergarten.

After obtaining a draft of an early childhood development assessment model in preliminary research, the next step is to realize the prototype of the assessment model draft through the creation of an Android application. This research in the first year will produce: (1) revision of the guidelines for child development assessment model; (2) prototype of the android-based child development assessment model; and (3) and limited testing of the prototype of the android-based child development assessment model. The Android-based Child Development Assessment Model developed will be validated by experts before conducting a limited trial for kindergarten teachers, both from early childhood assessment experts and technology experts.

\section{B. Android-Based Assessment Application}

The design of this application is based on the results of research by looking at the needs of assessment techniques commonly used by kindergarten teachers. Through the application to be developed, it is hoped that rapid, accurate and comprehensive early childhood development can be recorded. This study develops a draft of an online android-based early childhood development assessment model "MATAGURU". After this prototype has been developed, expert validation is first done before testing is limited to kindergarten teachers, both from early childhood assessment experts and technology experts. 
Validation from experts will be analyzed according to needs and then the prototype will be tested on the effectiveness of the child development assessment model with "MATAGURU" application in kindergarten DKI Jakarta, Indonesia. The prototype design of this application was developed by the proposing team with the development team and discussed with experts. This assessment application can be downloaded by the teacher through Play-Store. The description of the application "Mata Guru" is as follows:

\section{Login Page}

The login page functions to enter the application, if the teacher already has a username and password. Teachers can register in advance on the application before being able to login to enter into the application. When registering, the teacher will enter his data or identity as the user of the "MATAGURU" application. After completing registration, the teacher will easily log into the application and use the application comfortably.

\section{General Homepage}

In this section application users will go to a page that displays several items or functions. This page appears after users enter the application; users will enter the general homepage / dashboard page. In the dashboard there are 6 functions, including:

- Total Activity, this contains an explanation of how many activities the user uses when using the application. For example, how many assessments have been done or how often are applications used by users.

- Total Students, this function will display how many students have been assessed by the teacher as the application user.

- Students, this function displays about student data that has been registered in the application used by the teacher. The teacher can add himself how many students will be assessed by the teacher each time the application is used.

- Anecdotes, one of the assessment techniques that can be selected by the user in assessing children, especially for recording children's behavior in daily activities.

- Running record, assessment techniques that can be used by users in conducting assessments to see the sequence of events experienced by each student.

- Time Sampling, an assessment technique developed in the application of the assessment model that records how often or to see the frequency of a behavior seen in children while at school.

\section{Student Data}

Teachers as application users can add student data to be carried out assessments. On this page the function is to add students, into the application, the field consists of: Photos. Name and age. This page makes it easy for teachers to see student data that has been entered into the application and has been assessed continuously.

\section{Technical Assessment Options}

On this page displays a selection of assessment techniques that can be used by teachers in the application. The assessment technique developed by the proposer in this application is only the technique most often used by teachers in the field.

\section{CONCLUSION}

This assessment model includes several assessment techniques that can record all aspects of early childhood development. Through this application, can be recorded quickly about early childhood development, accurately and comprehensively. Subsequent research will be tested on the effectiveness of the child development assessment model with the application of "MATAGURU" in the DKI Jakarta Kindergarten, Indonesia.

\section{ACKNOWLEDGMENT}

The android-based early childhood development model is expected to help teachers in conducting early childhood development assessments easily and also have an impact on improving the kindergarten teacher's pedagogical competence. This application is also expected to provide input to the directorate of early childhood education, the ministry of education and culture in the development of online-based forms of child development assessment.

\section{REFERENCES}

[1] Ann S, Epstein, et.al. Preschool Assesment: A Guide to Developing A Balanced Approach. New Jersey: NIEER, 2004.

[2] Feeney, Stephanie Doris Christensen, and Eva Moravcik, Who Am I in The Live Of Children, New Jersey: Pearson Merill Prentice Hall, 2006.

[3] Hartati, Sofia. Tingkat Pengetahuan Guru TK tentang Asesmen Perkembangan Anak Usia Dini di TK Kelurahan Rawamangun, Jakarta, FIP UNJ:2012.

[4] HARTATI, S. (2017). Pengembangan Model Asesmen Perkembangan Anak Taman Kanak- Kanak Di Dki Jakarta. JPUD - Jurnal Pendidikan Usia Dini, 11(1), 19. https://doi.org/10.21009/jpud.111.02

[5] Kementerian Pendidikan dan Kebudayaan, Peraturan Menteri Pendidikan dan Kebudayaan Republik Indonesia No. 137 Tahun 2014 tentang Standar Nasional Pendidikan Anak Usia Dini, 2014

[6] Kostelnik,Marjorie J, Anne K. Soderman, Alice P. Whiren, Developmentally Approriate Curriculum, Best Practice In Early Childhood Education, New Jersey: Pearson Education Inc, 2007.

[7] Richey, R. C., \& Klein, J. D,Design and development research. Mahwah, NJ: Lawrence Erlbaum Associates, Publishers, 2007.

[8] Seefeldt, Carol, Sharon Castle, and Renee C. Falconer, Social Studies for the Preschool/Primary Child, Eighth Edition. New Jersey :Pearson, 2010.

[9] Sue. C. Wortham, Assesment in Early Childhood Education.NewJersey: Pearson, 2005.

[10] Van den Akker, J, Principles and methods of development research. In J. van den Akker, R. M.Branch, K. Gustafson, N. Nieveen \& T. Plomp (Eds.), Design approaches and tools in education andtraining. Norwell, MA: Kluwer Academic Publishers, 2000. 